\title{
PENGEMBANGAN MEDIA PEMBELAJARAN BERBASIS ANDROID PADA MATERI ARITMETIKA SOSIAL MENGGUNAKAN PENDEKATAN SAINTIFIK BERBANTUAN SOFTWARE CONSTRUCT 2 DI KELAS VII SMP NEGERI 137 JAKARTA
}

\author{
Siti Anisah ${ }^{1}$, Pinta Deniyanti ${ }^{2}$, Mimi Nur Hajizah ${ }^{3}$ \\ ${ }^{1}$ Prodi Pendidikan Matematika Universitas Negeri Jakarta \\ anisah.sa13@gmail.com \\ 2 Prodi Pendidikan Matematika Universitas Negeri Jakarta \\ Pinta_ds@yahoo.co.id \\ ${ }^{3}$ Prodi Pendidikan Matematika Universitas Negeri Jakarta \\ mimi.nurhajizah@gmail.com
}

\begin{abstract}
Abstrak
Penelitian ini dilatarbelakangi oleh analisis kebuutuhan siswa yang dilakukan pada tanggal 28 November 2018 di SMP Negeri 137 Jakarta. Siswa mengalami kesulitan pada materi aritmetika sosial sebesar $43,85 \%$. Sebanyak $54,71 \%$ siswa berpendapat bahwa materi tersebut seharusnya diajarkan dengan menggunakan media pembelajaran berbasis android. Penelitian ini bertujuan untuk mengembangkan media pembelajaran berbasis android menggunakan pendekatan saintifik yang dibuat dengan software Construct 2 pada materi aritmetika sosial. Untuk mencapai tujuan di atas, digunakan jenis penelitian pendidikan Research and Development (RnD) yang mengacu pada model penelitian Borg and Gall. Uji coba media dilaksanakan di SMP Negeri 137 Jakarta dengan melibatkan 31 siswa kelas VII. Media pembelajaran yang dihasilkan berupa aplikasi yang dapat dioperasikan menggunakan smartphone android. Media pembelajaran tersebut telah melalui validasi ahli media dengan nilai persentase rata-rata $77,19 \%$ dan dikategorikan valid. Hasil penilaian ahli materi dan bahasa diperoleh persentase rata-rata $83,77 \%$ dan dikategorikan sangat valid. Hasil penilaian oleh guru diperoleh persentase rata-rata $89,02 \%$ dan dikategorikan sangat valid. Sedangkan hasil akhir penilaian oleh siswa pada uji coba skala kecil dan skala besar masing-masing diperoleh nilai rata-rata 97,20\% dan 96,90\%. Sehingga, rata-rata keseluruhan adalah $88,77 \%$ yang berarti media pembelajaran yang dihasilkan layak dan dapat dimanfaatkan sebagai media pembelajaran matematika untuk kelas VII SMP.
\end{abstract}

Kata kunci: Media Pembelajaran, Android, Construct 2, Pendekatan Saintifik Aritmetika Sosial.

\section{PENDAHULUAN}

Munculnya era globalisasi membuat ilmu pengetahuan dan teknologi (IPTEK) berkembang pesat. Salah satu contoh perkembangan teknologi yang terjadi di Indonesia adalah penggunaan smartphone yang terus meningkat dari tahun ke tahun. Menurut laporan Emarkates, Indonesia akan melampaui seratus juta pengguna aktif ponsel pintar pada tahun 2018 dan akan menjadi negera dengan populasi pengguna ponsel pintar terbesar keempat di dunia setelah Cina, India, dan Amerika
Serikat. Perkembangan smartphone memiliki sistem operasi yang berbedabeda seperti iOS, Windows Phone, dan Android. Sistem operasi android adalah sistem operasi smartphone yang paling banyak digunakan di Indonesia. Tercatat $68,39 \%$ pengguna smartphone menggunakan android pada akhir tahun 2017.

Saat ini pengguna smartphone tidak hanya sebatas untuk berkomunikasi. Menurut hasil survei Asosiasi Penyelenggara Jasa Internet Indonesia 
(APJII) menyebutkan bahwa pada tahun 2017 sebanyak 89,35\% pengguna internet di Indonesia mengakses layanan chatting. Media sosial menduduki posisi kedua terbanyak dengan 87,13\%. Kemudian sebanyak 74,84\% pengguna internet melakukan layanan search engine untuk membantu pekerjaan mereka. Sedangkan $7,39 \%$ pengguna internet menggunakan untuk mengakses perbankan.

Berdasarkan hasil survei tersebut, terlihat bahwa pengguna smartphone di bidang pendidikan belum dimanfaatkan secara maksimal. Padahal penggunaan smartphone dalam dunia pendidikan memiliki peluang besar untuk meningkatkan kualitas mutu pendidikan di Indonesia. Penggunaan android sebagai media pembelajaran dapat memberikan kesempatan kepada siswa untuk belajar di manapun dan kapanpun. Di sisi lain, penggunaan media pembelajaran berbasis elektronik seperti android telah menjadi tuntutan bagi seorang pendidik di abad ke-21 dalam melakukan kegiatan belajar mengajar. Hal tersebut didasari oleh Undang-Undang Rebuplik Indonesia Nomor 14 tahun 2005 tentang guru dan dosen.

Namun yang terjadi di lapangan adalah banyaknya pendidik yang kurang berinovasi dalam memanfaatkan media pembelajaran. Kebanyakan pendidik hanya sebatas menggunakan program Power Point yang terkesan hanya memindahkan materi pembelajaran dari buku paket ke Power Point, sehingga siswa kurang berminat dalam belajar. Penerapan media pembelajaran berbasis android dapat menciptakan suasana baru dalam proses belajar. Melalui Android, unsur media seperti teks, grafis, gambar, audio, maupun video animasi dapat digabungkan menjadi satu kesatuan secara interaktif guna mendorong keberhasilan belajar. Muatan materi yang disertai gambar dan animasi dapat membantu siswa dalam memahami materi matematika yang sering dianggap sulit.
Berdasarkan hasil analisis kebutuhan, sebanyak $43,85 \%$ siswa mengaku bahwa materi aritmetika sosial sulit dikuasai. Hal ini dikarenakan terlalu banyak rumus yang harus dihafal untuk memecahkan soal materi tersebut. Selain itu, metode pengajaran yang dilakukan oleh guru hanya menjelaskan materi aritmetika sosial melalui papan tulis dan buku paket, dengan kata lain proses pembelajaran dengan pendekatan teachers center masih aktif di sekolah tersebut. Padahal pada kurikulum 2013, siswa dituntut untuk aktif dalam proses pembelajaran, sedangkan guru sebagai fasilitator.

Kurikulum 2013 menuntut para guru untuk menjadikan siswa sebagai pusat dalam kegiatan belajar mengajar. Menurut Liberna dan Wiratomo (2014), proses pembelajaran pada kurikulum 2013 untuk semua jenjang dilaksanakan dengan menggunakan pendekatan saintifik/ilmiah dan menyentuh tiga ranah, yaitu sikap, pengetahuan, dan keterampilan. Kemendikbud (2013) menambahkan bahwa keunggulan pendekatan saintifik dapat mendorong siswa untuk mampu berpikir kritis melalui serangkaian aktivitas yang menuntut siswa untuk lebih aktif dalam proses pembelajaran. Serangkaian aktivitas tersebut meliputi mengamati, menanya, mencoba, mengolah, menyajikan, menyimpulkan, dan mencipta.

Salah satu software yang dapat digunakan untuk membuat media pembelajaran adalah Construct 2. Construct 2 adalah sebuah perangkat lunak untuk membuat games berbasis Hyper Text Maxkup Language (HTML). Menurut Subagio (2014), perangkat lunak Construct 2 memiliki keunggulan yaitu tidak memerlukan bahasa pemrograman.

Berdasarkan uraian di atas, maka perlu dilakukan penelitian pengembangan media pembelajaran berbasis android pada materi aritmetika sosial menggunakan pendekatan saintifik untuk siswa kelas VII SMP Negeri 137 Jakarta. 
Rumusan masalah dalam penelitian ini adalah bagaimana mengembangkan media pembelajaran berbasis android yang dibuat dengan software Construct 2 pada materi aritmetika sosial menggunakan pendekatan saintifik untuk siswa kelas VII SMP Negeri 137 Jakarta. Adapun tujuan dari penelitian ini adalah untuk mengembangkan media pembelajaran berbasis android yang dibuat dengan software Construct 2 pada materi aritmetika sosial menggunakan pendekatan saintifik.

\section{METODE PENELITIAN}

\section{Jenis Penelitian}

Jenis penelitian ini adalah penelitian dan pengembangan (Research and Development) dengan menggunakan model pengembangan Borg and Gall. Adapun tahapan model pengembangan Borg and Gall menurut Winarni (2018) ada sepuluh tahapan, yaitu: (1) penelitian dan pengumpulan data, (2) perencanaan, (3) pengembangan produk awal, (4) Uji lapangan awal, (5) revisi hasil uji coba lapangan awal, (6) uji coba lapangan utama, (7) revisi hasil uji coba lapangan awal, (8) uji coba lapangan operasional, (9) penyempurnaan produk akhir, dan (10) desiminasi dan implementasi. Kesepuluh langkah tersebut disederhanakan menjadi enam tahapan dikarenakan keterbatasan waktu dan dana yang dimiliki. Adapun enam tahapan tersebut sebagai berikut:

1. Penelitian dan Pengumpulan Data

Tahapan yang dilakukan pada penelitian awal dan pengumpulan data adalah:

a. Studi Pustaka

Melakukan studi pustaka yang berhubungan dengan penelitian. Hasil studi pustaka berupa jurnal penelitian yang relevan dan kajian pustaka yang mendukung penelitian.

b. Survei Lapangan

Kegiatan ini bertujuan untuk menemukan masalah dasar yang dihadapi oleh guru dan siswa dalam proses pembelajaran matematika. Data mengenai fakta di lapangan dilakukan melalui pengisian angket pra penelitian oleh 45 siswa SMP Negeri 137 Jakarta. Selain itu, dilakukan wawancara kepada guru bidang studi matematika.

2. Perencanaan

Tahap perencanaan dimulai dengan pemetaan materi pembelajaran yang akan disampaikan. Pemetaan materi dimulai dengan menganalisis kurikulum, kompetensi inti, kompetensi dasar, indikator, serta tujuan pembelajaran pada materi aritmetika sosial yang berlaku di sekolah tempat penelitian. Pemetaan materi tersebut dijadikan bahan acuan untuk membuat Garis Besar Isi Media (GBIM).

3. Pengembangan Produk Awal

Langkah pertama dalam pengembangan media ini adalah membuat storyboard. Storyboard adalah sketsa desain awal dari tampilan produk yang akan dibuat dan fungsi bagian yang terkandung di dalamnya. Langkah selanjutnya membuat interface menggunakan program Adobe Photoshop CS6. Setelah sketsa desain awal dan interface dibuat maka langkah selanjutnya pembuatan produk media pembelajaran berbasis android melalui software Construct 2 yang dilanjutkan dengan pengujian pada smartphone android.

4. Uji Coba Lapangan Awal dan Revisi

Tahapan ini dilakukan bertujuan untuk mengetahui tingkat kelayakan dari produk yang dikembangkan sebelum produk tersebut digunakan dalam pembelajaran. Uji ini akan dilakukan oleh seorang ahli materi dan bahasa, serta ahli media.

Ahli materi dan bahasa akan memberikan kritik dan saran mengenai kesesuaian materi dalam media pembelajaran dengan kurikulum, penggunaan bahasa yang digunakan dalam aplikasi, menilai tingkat kesukaran dan variasi soal-soal yang digunakan. Sedangkan, ahli media akan memberikan kritik dan saran mengenai 
kemudahan dalam menggunakan aplikasi, menilai tampilan interface dan tombol-tombol yang disajikan, serta kesesuaian suara dan musik yang digunakan.

5. Uji Coba Lapangan Skala Kecil dan Revisi

Uji coba ini dilakukan oleh guru bidang studi matematika SMP Negeri 137 Jakarta dan 10 orang siswa kelas VII SMP Negeri 137 Jakarta. Media pembelajaran yang telah direvisi oleh para ahli kemudian diujicobakan kepada siswa. Setelah guru dan siswa menggunakan media pembelajaran yang telah dikembangkan oleh peneliti, masing-masing siswa diminta untuk memberikan masukan dan kritik dengan cara mengisi angket. Data hasil angket dijadikan sebagai masukan yang akan digunakan sebagai perbaikan produk sebelum diujikan pada uji coba skala besar.

6. Uji Coba Lapangan Besar

Produk yang telah direvisi pada uji coba lapangan kecil selanjutnya diujicobakan pada uji coba lapangan skala besar. Responden pada uji coba lapangan skala besar adalah 31 siswa yang merupakan kelas VII. Setelah uji coba lapangan besar dilakukan, responden diminta untuk mengisi angket yang telah diberikan. Data hasil angket dijadikan sebagai masukan yang akan digunakan sebagai perbaikan atau revisi produk sehingga produk yang dihasilkan menjadi semakin sempurna.

\section{Instrumen Pengumpulan Data}

Instrumen penelitian yang digunakan berupa angket pra penelitian dan angket validasi. Angket pra penelitian berisi pendapat siswa mengenai pemahaman materi, karakteristik materi, kegiatan pembelajaran yang diinginkan, dan ketertarikan siswa terhadap penggunaan media pembelajaran. Angket validasi berupa penilaian dan tanggapan terhadap media, penggunaan media, desain media, dan kemenarikan media. Angket tersebut ditujukan untuk ahli materi dan bahasa, ahli media, dan siswa kelas VII SMP Negeri 137 Jakarta.

Angket yang akan dibagikan kepada siswa merupakan angket kombinasi antara terbuka dan tertutup, serta menggunakan skala Ghuttman dengan dua alternatif jawaban ya dan tidak. Sedangkan, angket yang dibagikan kepada ahli materi dan bahasa, serta ahli media merupakan angket tertutup dengan menggunakan skala likert dengan lima alternatif jawaban; sangat baik, baik, cukup, kurang, dan kurang baik.

\section{Teknik Analisis Data}

Data hasil angket yang diperoleh dari pengisian uji validitas oleh ahli materi dan bahasa, ahli media, dan guru dianalisis dengan langkah sebagai berikut.

1. Tabulasi data yang diperoleh dari hasil angket dengan mengelompokkan butirbutir penyataan sesuai dengan aspekaspek yang diamati. Penyekoran berdasarkan perhitungan penilaian skala likert dengan rentang poin $1-5$.

Tabel 1. Skala likert untuk Penilaian

\begin{tabular}{|c|c|c|}
\hline No. & Alternatif Jawaban & Bobot Skor \\
\hline 1. & Sangat Baik & 5 \\
\hline 2. & Baik & 4 \\
\hline 3. & Cukup & 3 \\
\hline 4. & Kurang & 2 \\
\hline 5. & Sangat Kurang & 1 \\
\hline
\end{tabular}

(Sumber: Sugiyono, 2015)

2. Menghitung persentase skor masingmasing aspek yang diamati dengan rumus:

$$
\text { Persentase skor }=\frac{\sum \text { skor perolehan }}{\sum \text { skor maksimum }} \times 100 \%
$$

3. Menghitung persentase rata-rata skor angket

4. Mengonversikan persentase rata-rata skor angket yang diperoleh menjadi nilai kualitatif berdasarkan tingkat kevalidan. Adapun tingkat kevalidan ditetapkan seperti pada tabel 2 .

Produk dikatakan layak apabila tingkat kevalidan yang dicapai minimal adalah klasifikasi baik atau persentase 
rata-rata skor angket tidak kurang dari $61 \%$.

Tabel 2. Katagori Tingkat Kevalidan dengan Modifikasi

(Sumber: Riduwan, 2008)

Sedangkan data hasil angket yang diperoleh dari uji coba lapangan besar oleh 31 siswa kelas VII SMP Negeri 137 Jakarta dianalisis dengan langkah sebagai berikut:

1. Memeriksa jawaban angket yang diisi oleh siswa

2. Merekapitulasi jawaban angket mengenai tanggapan siswa terhadap media pembelajaran berbasis android yang digunakan. Adapun perolehan skor untuk masing-masing jawaban adalah untuk jawaban "Ya" mendapatkan skor 1 dan untuk jawaban "Tidak" mendapatkan skor 0 .

3. Menghitung persentase skor masingmasing aspek yang diamati dengan rumus:

Persentase skor $=\frac{\sum \text { skor } \text { perolehan }}{\sum \text { skor } \text { maksimum }} \times 100 \%$

4. Menghitung persentase rata-rata skor angket

5. Mengonversikan persentase rata-rata skor angket yang diperoleh menjadi nilai kualitatif berdasarkan katagori respon siswa yang terdapat pada Tabel 3.7.

Tabel 3. Kriteria Respon Siswa

\begin{tabular}{|c|c|}
\hline Persentase (\%) & Kriteria \\
\hline $85 \leq \mathrm{RS}$ & Sangat Positif \\
\hline $70 \leq \mathrm{RS} \leq 85$ & Positif \\
\hline $50 \leq \mathrm{RS} \angle 70$ & Kurang Positif \\
\hline $\mathrm{RS}<50$ & Tidak Positif \\
\hline
\end{tabular}

(Sumber: Kiswanto, 2012)

Kriteria sangat positif/ positif memiliki arti bahwa media yang dikembangkan diperlukan dan digunakan untuk pembelajaran formal selanjutnya, kriteria kurang positif memiliki arti bahwa media pembelajaran yang dikembangkan dapat digunakan atau tidak perlu digunakan untuk pembelajaran selanjutnya, dan kriteria tidak positif memiliki arti bahwa media pembelajaran yang dikembangkan tidak perlu digunakan dalam pembelajaran selanjutnya.

\section{HASIL DAN PEMBAHASAN}

\begin{tabular}{|c|c|c|}
\hline Persentase $(\%)$ & Kategori & Keterangan \\
\hline $80<$ skor $\leq 100$ & $\begin{array}{c}\text { Sangat } \\
\text { valid }\end{array}$ & Tidak revisi \\
\hline $60<$ skor $\leq 80$ & Valid & Tidak revisi \\
\hline $40<$ skor $\leq 60$ & $\begin{array}{c}\text { Cukup } \\
\text { Valid }\end{array}$ & $\begin{array}{c}\text { Sebagian } \\
\text { Revisi }\end{array}$ \\
\hline $20<$ skor $\leq 40$ & $\begin{array}{c}\text { Kurang } \\
\text { Valid }\end{array}$ & Revisi \\
\hline $0<$ skor $\leq 20$ & $\begin{array}{c}\text { Sangat } \\
\text { Kurang } \\
\text { Valid }\end{array}$ & Revisi \\
\hline
\end{tabular}

Penelitian dan pengembangan yang dilakukan menghasilkan media pembelajaran berbasis android yang dikembangkan menggunakan software Construct 2 pada materi aritmetika sosial dengan pendekatan saintifik. Pengembangan media pembelajaran tersebut melalui enam tahapan yaitu:

1. Penelitian dan Pengumpulan Data

Langkah awal dalam tahap ini adalah melakukan analisis kebutuhan siswa pada tanggal 28 November 2018 di SMP Negeri 137 Jakarta. Hasil analisis kebutuhan dengan menyebarkan angket kepada 45 responden siswa kelas VIII adalah sebanyak $93 \%$ siswa menganggap matematika merupakan pelajaran tersulit dan 43,85\% memilih materi aritmetika sebagai materi matematika tersulit. Selain itu sebanyak 54,71\% berpendapat bahwa materi yang dianggap sulit tersebut seharusnya diajarkan oleh guru dengan menggunakan media pembelajaran berbasis android untuk membantu dalam belajar dan $41,26 \%$ siswa menginginkan media pembelajaran yang mudah dibawa dan dipelajari.

Selanjutnya dilakukan wawancara dengan guru matematika di SMP Negeri 137 Jakarta. Berdasarkan wawancara, guru menyatakan bahwa pada saat proses pembelajaran guru hanya menjelaskan materi tanpa menggunakan 
media pembelajaran yang dapat menarik perhatian siswa dikarenakan keterbatasan media yang tersedia di sekolah. Media yang sering digunakan guru adalah speaker agar suara guru dapat terdengar jelas oleh siswa yang duduk di baris belakang.

\section{Perencanaan}

Berdasarkan kurikulum 2013 yang ditetapkan oleh Badan Standar Nasional Pendidikan (BSNP), materi aritmetika sosial adalah materi matematika untuk kelas VII SMP di semester genap. Adapun Kompetensi Dasar dan Indikator Pencapaian Kompetensi seperti yang ditampilkan pada tabel 4 .

Tabel 4. Kompetensi Dasar dan Indikator Pencapaian Kompetensi

\begin{tabular}{|c|c|}
\hline Dasar & $\begin{array}{l}\text { Indikator Pencapaian } \\
\text { Kompetensi }\end{array}$ \\
\hline \multirow{4}{*}{$\begin{array}{l}\text { 3.9 Mengenal } \\
\text { aritmetika sosial } \\
\text { (penjualan, } \\
\text { pembelian, } \\
\text { potongan, } \\
\text { keuntungan, } \\
\text { kerugian, bunga } \\
\text { tunggal, } \\
\text { persentasi, } \\
\text { bruto, neto, } \\
\text { tara) }\end{array}$} & $\begin{array}{l}\text { 3.9. } 1 \text { Menjelaskan } \\
\text { pengertian dan } \\
\text { hubungan harga jual dan } \\
\text { harga beli. }\end{array}$ \\
\hline & $\begin{array}{l}\text { 3.9.2 Menghitung } \\
\text { untung, rugi, persentase } \\
\text { untung, dan persentase } \\
\text { rugi. }\end{array}$ \\
\hline & $\begin{array}{l}\text { 3.9.3 Menentukan besar } \\
\text { diskon, bruto, tara, dan } \\
\text { netto. }\end{array}$ \\
\hline & $\begin{array}{l}\text { 3.9.4 Menentukan besar } \\
\text { bunga tunggal dan pajak }\end{array}$ \\
\hline \multirow{3}{*}{$\begin{array}{l}\text { 4.9Menganalisis } \\
\text { berbagai situasi } \\
\text { aritmetika sosial } \\
\text { (penjualan, } \\
\text { pembelian, } \\
\text { potongan, } \\
\text { keuntungan, } \\
\text { kerugian, bunga } \\
\text { tunggal, } \\
\text { persentasi, } \\
\text { bruto, neto, } \\
\text { tara) }\end{array}$} & $\begin{array}{l}\text { 4.9.1 Menyelesaikan } \\
\text { soal cerita yang } \\
\text { berkaitan dengan harga } \\
\text { jual, harga beli, } \\
\text { keuntungan, kerugian. }\end{array}$ \\
\hline & $\begin{array}{l}\text { 4.9.2 Menyelesaikan } \\
\text { soal cerita yang } \\
\text { berkaitan dengan } \\
\text { persentase untung dan } \\
\text { persentase rugi. }\end{array}$ \\
\hline & $\begin{array}{l}\text { 4.9.3 Menyelesaikan } \\
\text { soal cerita yang } \\
\text { berkaitan dengan } \\
\text { diskon, bruto, tara, dan } \\
\text { netto. }\end{array}$ \\
\hline
\end{tabular}

4.9.4 Menyelesaikan soal cerita yang berkaitan dengan bunga tunggal dan pajak.

Sumber: Kementerian Pendidikan dan Kebudayaan (2013: 55)

3. Pengembangan Produk Awal

Media pembelajaran yang dikembangkan menggunakan program Construct 2. Selain itu, menggunakan beberapa program lainnya, seperti Microsoft Word 2010 untuk membuat Garis Besar Isi Media (GBIM) dan storyboard dan program Adobe Photoshop CS6 untuk membuat tampilan interface. Berikut adalah tampilan media pembelajaran yang dikembangkan.

Gambar 1 merupakan tampilan intro dari media pembelajaran berbasis android pada materi aritmetika sosial. Tampilan intro berisi identitas dari pengembang dan nama produk media pembelajaran yang dikembangkan. Setelah tiga detik tampilan intro ditampilkan, kemudian tampilan akan beralih ke halaman berikutnya yaitu halaman pembuka.

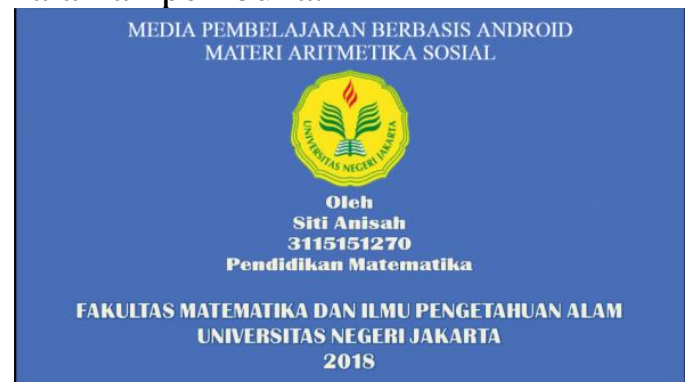

Gambar 1. Tampilan Intro

Gambar 2 merupakan tampilan pembuka dengan gambar latar yang menunjukan kegunaan dari materi aritmetika di kehidupan sehari-hari, misalnya transaksi jual beli dan kegiatan bank seperti menabung atau meminjam uang di bank. Apabila tombol mulai tersebut diklik, maka akan berpindah ke halaman menu utama. 


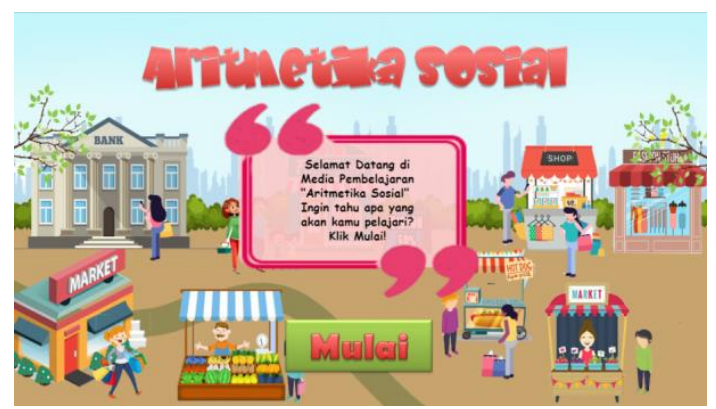

Gambar 2. Tampilan Pembuka

Pada menu utama terdapat beberapa tombol dan pilihan menu, yaitu tombol menu halaman pembuka, tombol pengatur suara, tombol profil, tombol setting, pilihan menu petunjuk, menu kompetensi dan tujuan, menu pilihan materi, menu evaluasi, menu games, dan pilihan menu keluar.

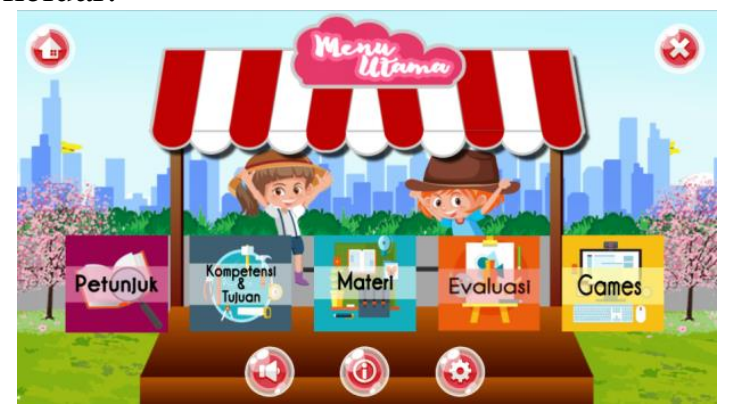

Gambar 3. Menu Utama

Selanjutnya, jika pengguna ingin mengetahui petunjuk penggunaan media pembelajaran berbasis android ini pengguna dapat membuka halaman petunjuk dengan menekan pilihan menu petunjuk.

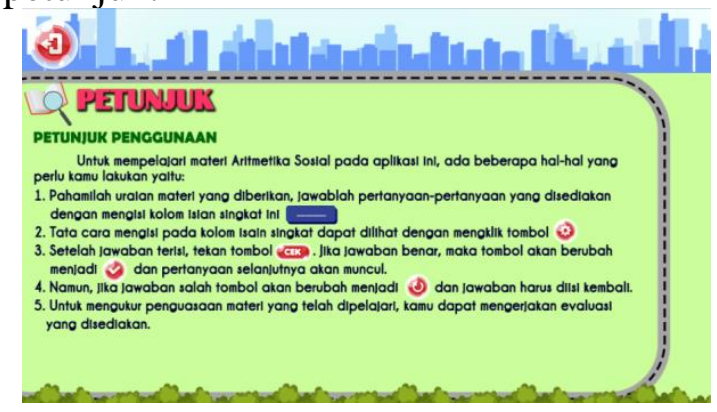

Gambar 4. Menu Petunjuk

Sedangkan apabila pengguna ingin mengetahui fungsi dari beberapa tombol, pengguna dapat menekan tombol setting (pengaturan). Tombol pengaturan akan ada di setiap materi yang ditampilkan.

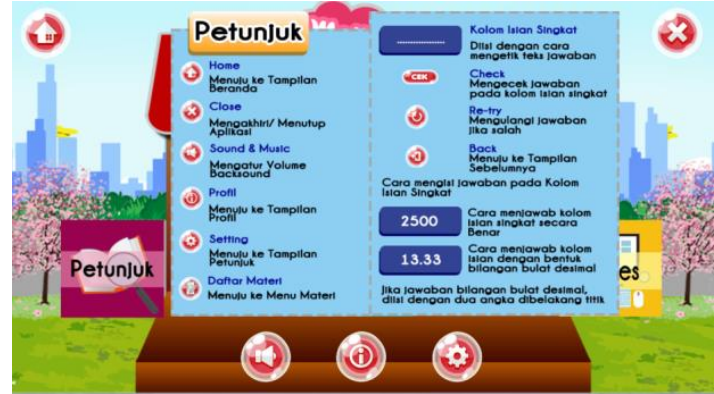

Gambar 5. Tombol Pengaturan

Jika pengguna ingin mengetahui standar isi yang menjadi acuan penyajian materi, pengguna dapat menekan pilihan menu kompetensi dan tujaun. Apabila pilihan menu kompetensi dan tujuan ditekan maka akan muncul halaman yang akan menampilkan kompetensi dasar dan indikator dari materi aritmetika sosial berdasarkan kurikulum 2013.

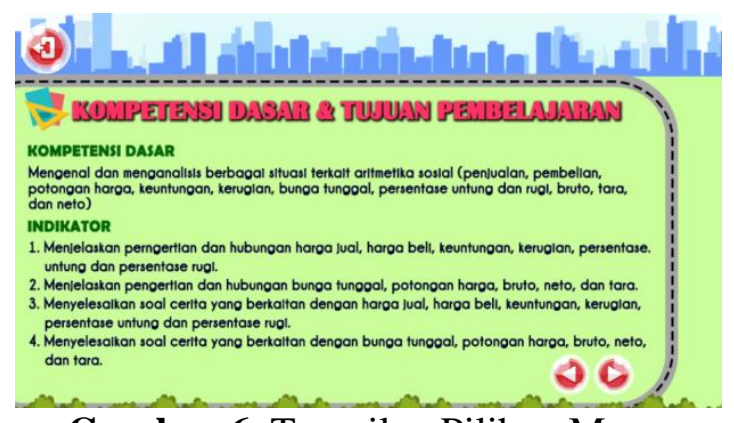

Gambar 6. Tampilan Pilihan Menu Kompetensi

Untuk dapat melihat tampilan menu tujuan pembelajaran, pengguna dapat menekan tombol panah ke kanan yang terletak di bagian bawah menu kompetensi dasar. Tujuan pembelajaran yang ditampilkan di media pembelajaran yang dikembangkan mengacu pada kegiatan belajar siswa pada materi aritmetika yang dijabarkan pada silabus mata pelajaran matematika untuk sekolah menengah pertama. 


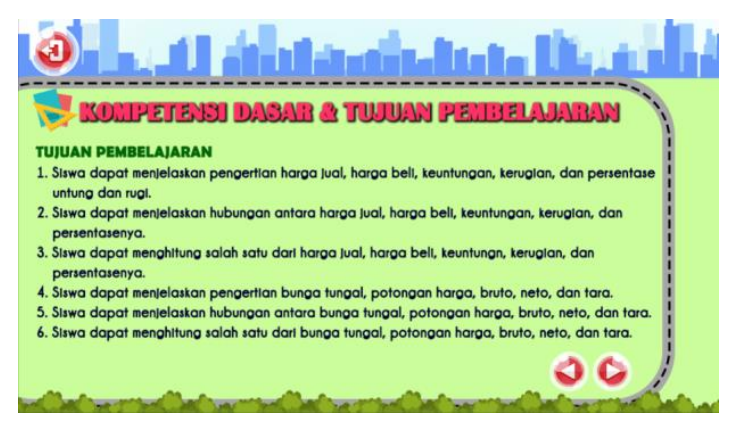

Gambar 7. Tampilan Tujuan Pembelajaran

Setelah melihat standar isi media pembelajaran berbasis android, pengguna dapat memulai proses pembelajaran materi aritmetika sosial dengan meneken pilihan menu materi. Setelah memilih menu materi kemudian akan berpindah ke halaman menu sub materi. Pada menu materi terdapat tombol daftar nilai, apabila tombol tersebut ditekan maka akan menampilkan hasil capaian dari setiap sub materi yang telah dipelajari oleh pengguna.

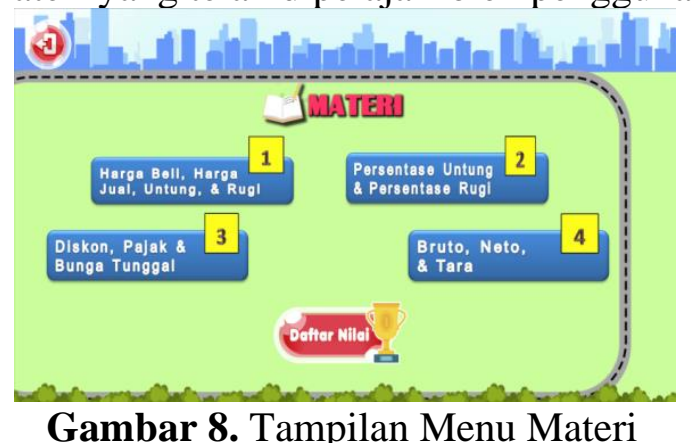

Halaman materi menampilkan sub materi yang akan dipelajari, yaitu harga beli, harga jual, untung, rugi, persentase untung dan rugi, potongan harga, bunga tunggal dan pajak, bruto, neto, dan tara. Materi tersebut akan disajikan dengan menggunakan pendekatan saintifik, yang terdiri dari aktivitas mengamati, menanya, menalar atau mengeksplorasi, mencoba, dan mengomunikasikan.

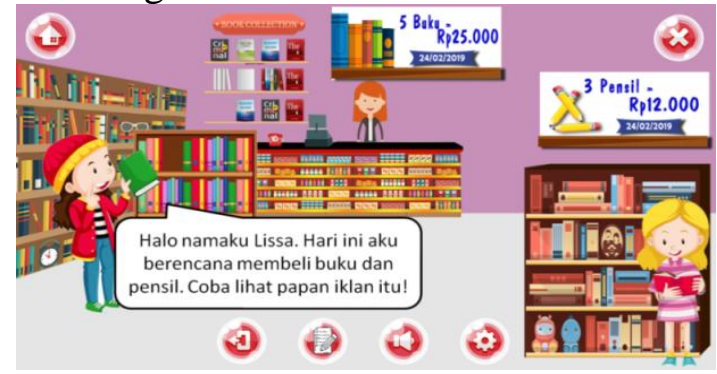

(a) Aktivitas mengamati

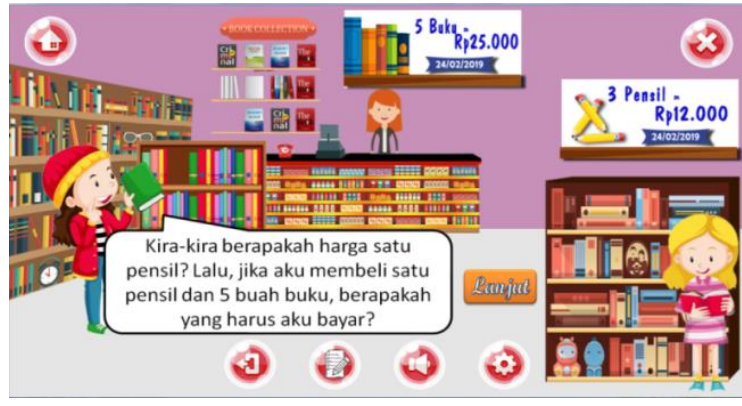

(b) Aktivitas menanya

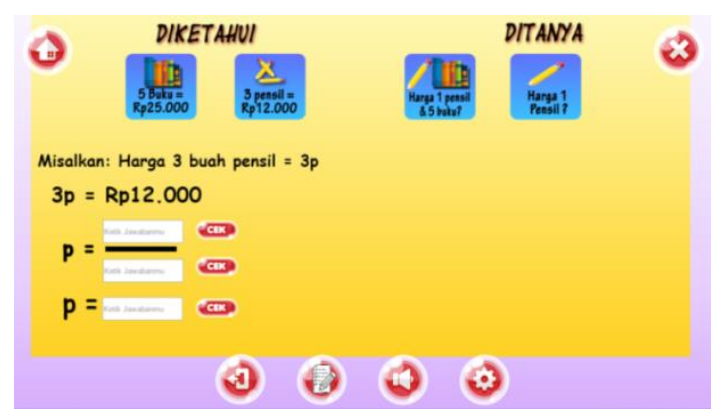

(c) Aktivitas menalar

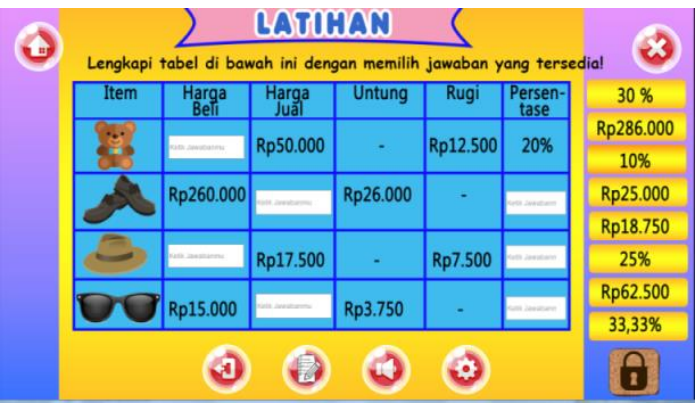

(d) Aktivitas mencoba

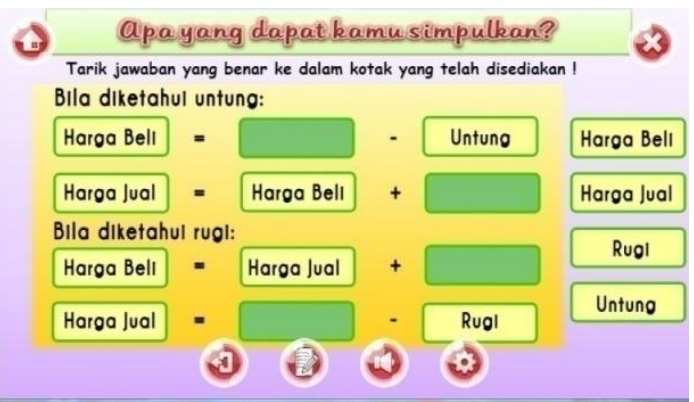

(e) Aktivitas mengomunikasikan

Gambar 9 Aktivitas Pendekatan Saintifik

Gambar 9 merupakan penerapan pendekatan saintifik yang ada dalam media pembelajaran berbasis android. Aktivitas pembelajaran berdasarkan kegiatan yang terdapat pada pendekatan saintifik adalah mengamati, menanya, menalar atau 
mengeksplorasi, mencoba, dan mengomunikasikan.

Gambar 10 menunjukan tampilan dari umpan balik. Umpan balik ini terdapat di setiap akhir kegiatan belajar. Umpan balik tersebut berisi nilai kemampuan mengidentifikasi masalah, kemampuan menjawab soal, dan nilai secara keseluruhan.

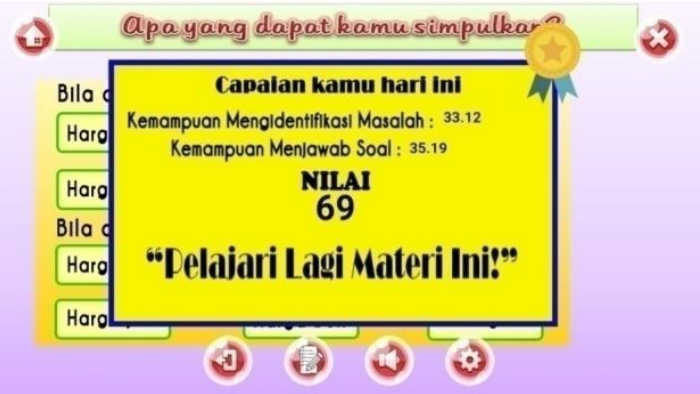

Gambar 10. Umpan Balik

Setelah mempelajari sub materi yang ada pada menu materi, pengguna dapat melakukan evaluasi. Soal evaluasi terdiri dari 10 soal dalam bentuk pilihan ganda. Siswa diberikan waktu selama 20 menit untuk mengerjakan evaluasi. Soal-soal dalam evaluasi mengacu pada indikator pembelajaran. Jika semua soal telah dijawab akan beralih ke halaman hasil evaluasi yang akan menampilkan skor yang diperoleh pengguna.

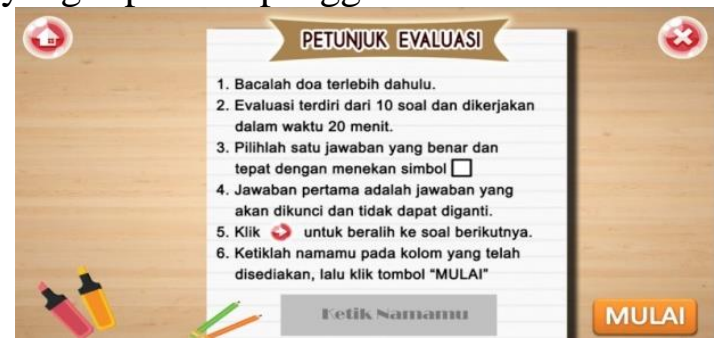

(a) Tampilan petunjuk evaluasi

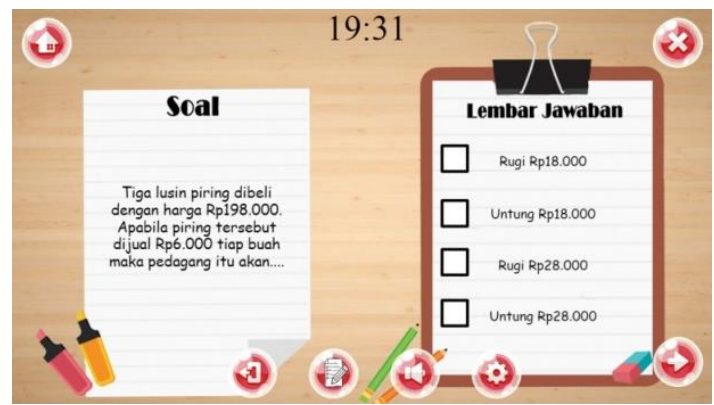

(b) Tampilan soal pada evaluasi

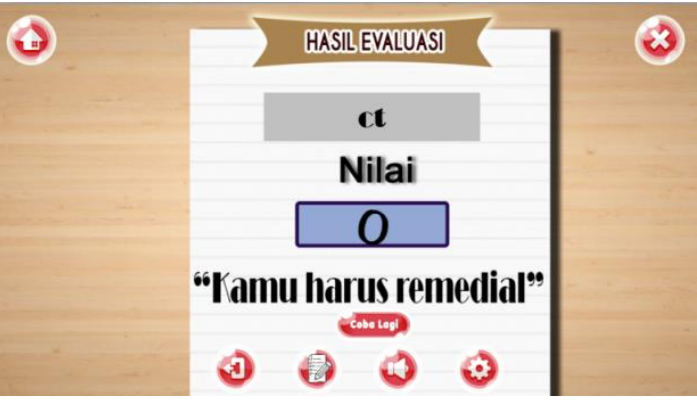

(c) Tampilan hasil evaluasi

Gambar 11. Tampilan Halaman Evaluasi

Media pembelajaran berbasis android ini juga menyisipkan soal latihan tambahan dalam bentuk permainan. Pengguna dapat menekan menu pilihan games yang terdapat pada halaman menu utama dan selanjutnya akan beralih ke halaman games. Pada halaman games terdiri dari dua jenis permainan yaitu "Who Wants to be Mathematics" dan "Tic Tac Toe." Masing-masing permainan akan menampilkan pertanyaan mengenai aritmetika sosial. Pertanyaan dalam permainan "Who Wants to be Mathematics" berupa pilihan ganda sebanyak 15 soal yang akan ditampilkan secara acak. Sedangkan untuk permainan "Tic Tac Toe" dimuat dengan bentuk soal esai dengan jumlah soal sebanyak 9 soal.

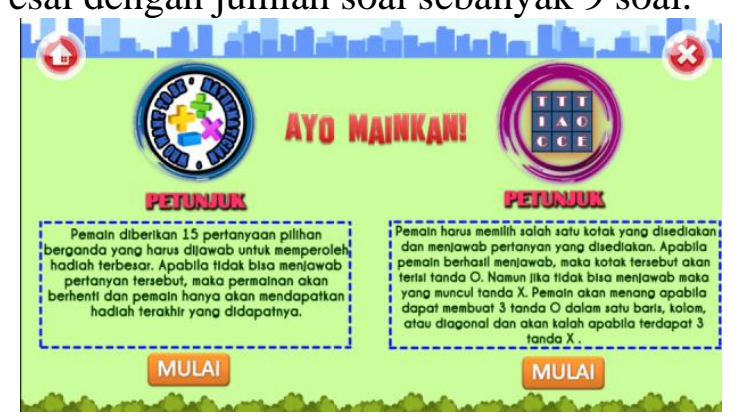

(a) Halaman menu pilihan games

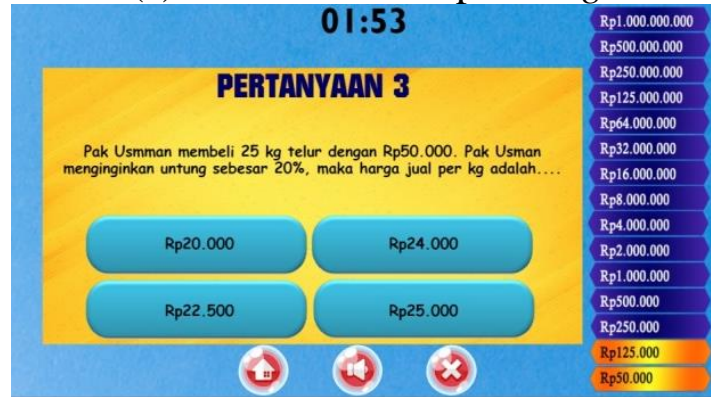

(b) Permainan Who Wants to be Mathematics 


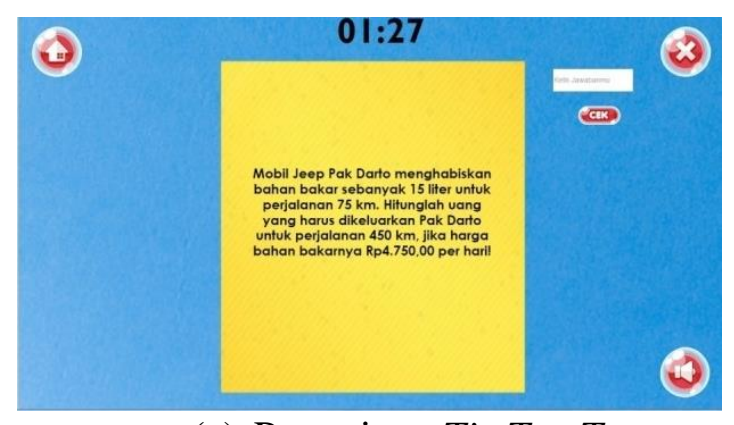

(c) Permainan Tic Tac Toe

Gambar 12. Tampilan Menu Games

4. Uji Coba Lapangan Awal dan Revisi

Pada tahap ini dilakukan penilaian media pembelajaran yang dikembangkan oleh validator ahli materi dan bahasa, serta ahli media yang ahli dibidangnya. Jika ditemukan kekurangan akan segera dilakukan revisi.

Berdasarkan penilaian ahli media dapat disimpulkan media pembelajaran yang dihasilkan valid dengan persentase rata-rata keseluruhan $77,19 \%$. Sedangkan, penilaian ahli materi dan bahasa memperoleh persentase keseluruhan $83,77 \%$ yang dikategorikan sangat valid. Berikut hasil penilaian media oleh ahli materi dan bahasa, serta ahli media.

Tabel 5. Penilaian oleh Ahli Media

\begin{tabular}{|l|c|l|}
\hline \multicolumn{1}{|c|}{$\begin{array}{c}\text { Aspek } \\
\text { yang } \\
\text { diukur }\end{array}$} & $\begin{array}{c}\text { Persen- } \\
\text { tase }\end{array}$ & $\begin{array}{c}\text { Katego- } \\
\text { ri }\end{array}$ \\
\hline $\begin{array}{l}\text { Kesesuaian Isi } \\
\text { Media Pembelajaran }\end{array}$ & $78,75 \%$ & Valid \\
\hline Teknik Penyajian & $75 \%$ & Valid \\
\hline $\begin{array}{l}\text { Rekayasa Perangkat } \\
\text { Lunak }\end{array}$ & $80 \%$ & Valid \\
\hline Kebahasaan & $75 \%$ & Valid \\
\hline
\end{tabular}

Tabel 6. Penilaian oleh Ahli Matari dan Bahasa

\begin{tabular}{|l|c|l|}
\hline \multicolumn{1}{|c|}{$\begin{array}{c}\text { Aspek yang } \\
\text { diukur }\end{array}$} & $\begin{array}{c}\text { Persen- } \\
\text { tase }\end{array}$ & $\begin{array}{c}\text { Katego } \\
\text {-ri }\end{array}$ \\
\hline $\begin{array}{l}\text { Isi Media } \\
\text { Pembelajaran } \\
\text { Secara Umum }\end{array}$ & $83,33 \%$ & $\begin{array}{l}\text { Sangat } \\
\text { valid }\end{array}$ \\
\hline
\end{tabular}

\begin{tabular}{|l|c|l|}
\hline $\begin{array}{l}\text { Sistematika Isi } \\
\text { Media } \\
\text { Pembelajaran }\end{array}$ & $86 \%$ & $\begin{array}{l}\text { Sangat } \\
\text { valid }\end{array}$ \\
\hline Cakupan Materi & $84 \%$ & $\begin{array}{l}\text { Sangat } \\
\text { valid }\end{array}$ \\
\hline $\begin{array}{l}\text { Pendekatan } \\
\text { Saintifik }\end{array}$ & $82,50 \%$ & $\begin{array}{l}\text { Sangat } \\
\text { valid }\end{array}$ \\
\hline Kebahasaan & $83,77 \%$ & $\begin{array}{l}\text { Sangat } \\
\text { valid }\end{array}$ \\
\hline
\end{tabular}

5. Uji Coba Skala Kecil dan revisi

Uji coba ini dilakukan oleh seorang guru matematika dan 10 siswa kelas VII SMP Negeri 137 Jakarta. Uji coba dengan guru diawali dengan memberikan media pembelajaran berbasis android dengan mengirimkan file aplikasi melalui fitur bluetooth. Setelah berhasil terkirim, guru langsung meng-install dan mulai menggunakan media tersebut sekaligus memberikan penilaian. Sedangkan uji coba dengan sepuluh siswa denga meminjamkan smarthphone android yang telah terinstal aplikasi media yang dikembangkan. Berikut hasil penilaian media oleh guru dan siswa pada uji coba skala kecil.

Tabel 7. Penilaian oleh Guru

\begin{tabular}{|l|c|l|}
\hline $\begin{array}{l}\text { Aspek yang } \\
\text { diukur }\end{array}$ & Persentase & Kategori \\
\hline $\begin{array}{l}\text { Isi Media } \\
\text { Pembelajaran } \\
\text { Secara Umum }\end{array}$ & $84,44 \%$ & $\begin{array}{l}\text { Sangat } \\
\text { valid }\end{array}$ \\
\hline $\begin{array}{l}\text { Sistematika Isi } \\
\text { Media } \\
\text { Pembelajaran }\end{array}$ & $92 \%$ & $\begin{array}{l}\text { Sangat } \\
\text { valid }\end{array}$ \\
\hline $\begin{array}{l}\text { Cakupan } \\
\text { Materi }\end{array}$ & $84 \%$ & $\begin{array}{l}\text { Sangat } \\
\text { valid }\end{array}$ \\
\hline $\begin{array}{l}\text { Pendekatan } \\
\text { Saintifik }\end{array}$ & $92 \%$ & $\begin{array}{l}\text { Sangat } \\
\text { valid }\end{array}$ \\
\hline $\begin{array}{l}\text { Teknis } \\
\text { Penyajian }\end{array}$ & $91,67 \%$ & $\begin{array}{l}\text { Sangat } \\
\text { valid }\end{array}$ \\
\hline $\begin{array}{l}\text { Kebahasaan } \\
\text { Rebangat } \\
\text { valid }\end{array}$ \\
\hline $\begin{array}{l}\text { Rata-Rata } \\
\text { Keselurhan }\end{array}$ & $\mathbf{8 9 , 0 2 \%}$ & $\begin{array}{l}\text { Sangat } \\
\text { Valid }\end{array}$ \\
\hline
\end{tabular}


Tabel 8. Penilaian oleh Sepuluh Siswa

\begin{tabular}{|c|c|c|}
\hline $\begin{array}{l}\text { Aspek yang } \\
\text { diukur }\end{array}$ & Persentase & Kategori \\
\hline $\begin{array}{l}\text { Kesesuaian Isi } \\
\text { Media } \\
\text { Pembelajaran }\end{array}$ & $98,18 \%$ & $\begin{array}{l}\text { Sangat } \\
\text { valid }\end{array}$ \\
\hline $\begin{array}{l}\text { Teknik } \\
\text { Penyajian } \\
\text { Media } \\
\end{array}$ & $98,75 \%$ & $\begin{array}{l}\text { Sangat } \\
\text { valid }\end{array}$ \\
\hline $\begin{array}{l}\text { Rekayasa } \\
\text { Perangkat } \\
\text { Lunak }\end{array}$ & $90 \%$ & $\begin{array}{l}\text { Sangat } \\
\text { valid }\end{array}$ \\
\hline Kebahasaan & $100 \%$ & $\begin{array}{l}\text { Sangat } \\
\text { valid }\end{array}$ \\
\hline $\begin{array}{l}\text { Rata-Rata } \\
\text { Keselurhan }\end{array}$ & $97,20 \%$ & $\begin{array}{l}\text { Sangat } \\
\text { Valid }\end{array}$ \\
\hline
\end{tabular}

\section{Uji Coba Skala Besar}

Tahapan ini dilakukan pada hari Jumat, 10 Mei 2019 dengan melibatkan 31 siswa kelas VII SMP Negeri 137 Jakarta. Saat uji coba skala besar masing-masin siswa diminta untuk membawa smartphone android yang telah terinstal aplikasi media pembelajaran. Setelah siswa menggunakan media pembelajaran yang dikembangkan, siswa diminta untuk mengisi angket penilaian media. Berikut hasil angket penilaian media pada uji coba skala besar.

Tabel 9. Penilaian Media Uji Coba Skala Besar

\begin{tabular}{|l|c|l|}
\hline $\begin{array}{l}\text { Aspek yang } \\
\text { diukur }\end{array}$ & Persentase & Kategori \\
\hline $\begin{array}{l}\text { Kesesuaian Isi } \\
\text { Media } \\
\text { Pembelajaran }\end{array}$ & $99,12 \%$ & $\begin{array}{l}\text { Sangat } \\
\text { valid }\end{array}$ \\
\hline $\begin{array}{l}\text { Teknik } \\
\text { Penyajian } \\
\text { Media }\end{array}$ & $95,97 \%$ & $\begin{array}{l}\text { Sangat } \\
\text { valid }\end{array}$ \\
\hline $\begin{array}{l}\text { Rekayasa } \\
\text { Perangkat } \\
\text { Lunak }\end{array}$ & $92,74 \%$ & $\begin{array}{l}\text { Sangat } \\
\text { valid }\end{array}$ \\
\hline $\begin{array}{l}\text { Kebahasaan } \\
\text { Rata-Rata } \\
\text { Keselurhan }\end{array}$ & $\mathbf{9 6 , 9 0 \%}$ & $\begin{array}{l}\text { Sangat } \\
\text { valid } \\
\text { Vangat }\end{array}$ \\
\hline
\end{tabular}

Berdasarkan penilaian pada tahapan di atas, rata-rata keseluruhan penilaian pada setiap tahapan mendapatkan persentase $88,77 \%$. Dengan demikian, media pembelajaran metamtika berbasis android pada materi aritmetika sosial dengan pendekatan saintifik dapat dikatakan layak dan dapat dimanfaatkan sebagai media pembelajaran matematika untuk kelas VII SMP.

\section{SIMPULAN DAN SARAN}

\section{Simpulan}

Penelitian dan pengembangan yang dilakukan menghasilkan media pembelajaran berbasis android yang dikembangkan menggunakan software Construct 2 pada materi aritmetika sosial dengan pendekatan saintifik. Pengembangan media pembelajaran tersebut melalui enam tahapan yaitu penelitian dan pengumpulan data, perencanaan, pengembangan produk awal, uji coba lapangan awal, uji coba skala kecil dan revisi, dan uji coba skala besar. Media pembelajaran yang dihasilkan sesuai dengan pendekatan saintifik yang mengacu pada kegiatan 5M (mengamati, menanya, menalar atau mengeksplorasi, mencoba, dan mengomunikasikan).

Berdasarkan hasil penilaian ahli media diperoleh persentase rata-rata $77,19 \%$ dan dikatagorikan valid. Hasil penilaian ahli materi dan bahasa diperoleh persentase rata-rata $83,77 \%$ dan dikatagorikan sangat valid. Hasil penilaian oleh guru diperoleh persentase rata-rata $89,02 \%$ dan dikatagorikan sangat valid. Sedangkan hasil akhir penilaian oleh siswa pada uji coba skala kecil dan skala besar masing-masing diperoleh nilai rata-rata 97,20\% dan 96,90\%. Dengan demikian, rata-rata keseluruhan dari penilaian pada setiap tahapan diperoleh persentase sebesar $88,77 \%$. Sehingga media pembelajaran matematika berbasis android pada materi aritmetika sosial dengan pendekatan saintifik layak dan dapat dimanfaatkan 
sebagai media pembelajaran matematika untuk kelas VII SMP.

\section{Saran}

Saran untuk penelitian

pengembangan media pembelajaran selanjutnya di antaranya:

1. Perlu dilakukan penelitian lanjutan untuk mengukur efektivitas hasil belajar matematika pada materi aritmetika sosial kelas VII dengan media pembelajaran ini.

2. Perlu dilakukan penelitian lanjutan mengenai pengembangan media pembelajaran dalam bentuk aplikasi smartphone lintas sistem operasi selain android, seperti $i O S$ dan Windows Phone.

3. Pembuatan background atau animasi masih menggunakan software Adobe Photoshop. Kombinasi software seperti Adobe Illustrator dan Corel Draw diperlukan untuk membuat animasi yeng lebih kreatif dan inovatif.

4. Pembuatan animasi dalam bentuk tiga dimensi diperlukan agar desain visual terkesan nyata seperti pada permainan (games) Player Unknown's Battle Grounds (PUBG).

5. Perlu dilakukan penelitian pengembangan media pembelajaran untuk materi pokok lain.

\section{DAFTAR PUSTAKA}

Chandra, Rizky. "Berapa Populasi OS Anroid pada akhir 2017?" Online. http://tekno.kompas.com/. Diakses pada tanggal 12 April 2019 pukul 11.44 WIB.

Izza, Jamalul. 2017. Penetrasi dan Perilaku Pengguna Internet di Indonesia. Jakarta: Publisher APJII.

Kementerian Pendidikan dan Kebudayaan. 2013. Diklat Guru dalam Rangka Implementasi Kurikulum 2013. Jakarta: Kemendikbud.
Kementerian Pendidikan dan Kebudayaan. 2013. Silabus Mata Pelajaran Matematika Sekolah Menengah Pertamal Madrasah Tsanawiyah (SMP/MTs). Jakarta: Depdiknas.

Kiswanto, Heri. 2012. "Pengembangan Media Pembelajaran Interaktif Berbantuan Komputer pada Materi Dimensi Tiga.” Jurnal MATHedunesa Volume 1 Nomor 1.

Liberna, Hawa dan Yogi Wiratom., 2014. Metode Pembelajaran Matematika. Jakarta: Penerbit Mitra Abadi.

Rahmayani, Indah. "Indonesia Raksasa Teknologi Digital Asia." Online. http://kominfo.go.id/content/detail/6 095/indonesia-raksasateknologidigital-asia/. Diakses 12 April 2019.

Riduwan. 2008. Metode \& Teknik Menyusun Tesis. Bandung: Alfabeta.

Subagio, Aryadi. 2014. Learning Construct 2. Birmingham: Packt Publishing.

Sugiyono. 2015. Metode Penelitian Pendidikan Pendekatan Kuantitatif, Kualitatif, dan RnD. Bandung: Alfabeta.

Winarni, Endang Widi. 2018. Teori dan Praktik Penelitian Kuantitatif, Kualitatif, PTK, dan R\&D. Jakarta: Bumi Aksara. 